\title{
Making of Test Instrument Based Higher Order Thinking Skills on Basic of Mechanics and Heat
}

\author{
Sabani $^{1}$, Yulifda Tanjung ${ }^{2}$ and Wawan Bunawan ${ }^{3}$ \\ \{sabani@unimed.ac.id $\left.{ }^{2}\right\}$ \\ Departement of Physics, Universitas Negeri Medan, Indonesia ${ }^{1,2,3}$
}

\begin{abstract}
This study aims to determine the quality of appropriateness products of test instruments based Higher Order Thinking Skill (HOTS) on Basic of Mechanics and Heat based on the Expert Team. The research method used in this study is Research and Development (R\&D) methods. The stages that will be carried out are: (1) preliminary study; (2) development study. In the preliminary stage is to study the learning tools, especially on the learning achievement of subjects and mid-semester exam questions and the final semester questions, where it is found that the learning achievement is still oriented towards Low Order Thinking Skill as well as mid-semester exam and final semester exams are still oriented towards low-level thinking. The next step is to conduct a development study by changing the achievement of learning oriented HOTS. Next, make a test instrument lattice based on learning achievement as a reference for making test instruments. From the results of the test instrument products that have been made then validated by two experts from the Department of Physics. From the results of the validation by the expert team, in general the test instruments were made in good categories according to HOTS criteria.
\end{abstract}

Keywords: Test Instrument, HOTS, Basic of Mechanics and Heat

\section{Introduction}

The 2016-2020 Medan State University strategic plan launched and developed State University of Medan to become a teaching and research institution that excels in producing scientific works. The research to be developed by Unimed is research, service, and science and technology that are useful for solutions to problems of education and the business world and the industrial world. Unimed also has to produce various learning developments, models and learning media, software, materials and systems to solve educational problems at the center of learning and research innovation. In accordance with that, it is necessary to conduct constructive treatments to build the characteristics of students. Then students must be prepared to be qualified and take a strategic role in future conditions.

Science, especially physics is very important role in driving the progress of Science and Technology (science and technology) because the development of physics is always pursued in accordance with the nature of learning towards the development of thinking abilities (mind on), skills (hands on), and scientific attitudes (heart on) (Asyhari, 2014) Physical learning is ideally in accordance with the objectives and nature of learning science, namely attitudes, processes, and products (Toharudin, 2011).

Changes in curriculum in universities are very urgent, where changes in curriculum will have an impact on university policies to develop more in all aspects, especially in the learning 
process. Since 2016, Medan State University began implementing and developing the Indonesian National Qualifications Framework (KKNI) Curriculum. The Indonesian National Qualification Framework (KKNI) is a manifestation of the quality and self-identity of the Indonesian people relating to the national education system, training and national learning achievement equality assessment system.

In applying the IQF curriculum in the lecture process in the classroom, it does not only focus on developing the learning model or strategy used. The provision of learning resources and the implementation of authentic assessment processes must also be considered by the lecturer as a learning facilitator. To be able to perform authentic assessment, an assessment instrument is needed that can be used as a reference as a standard instrument.

Basic Mechanics and Heat courses are basic Mathematics and Natural Sciences courses that must be taken by all students in the Faculty of Mathematics and Natural Sciences. Where in the assessment is done based on the results of 6 tasks (1. Routine tasks, 2. CBR, 3, CJR, 4, Idea Engineering, 5. Mini Research, and 6. Project) and Mid Semester examination results and End Semester Exams. The form of the midsemester exam is an Essay question and the form of a test for the semester final exam is a multiple choice form. Test instruments that have been tested have not been standardized based on the learning process carried out. When viewed from the learning process, students are required to think high-level. This can be seen from the tasks given which consist of 6 tasks. Therefore, in carrying out the Examination, a standard assessment instrument is needed to be used as a reference in the Faculty in assessing students and must also be adjusted to the mindset in the learning process, namely higher order thinking skills so that there is harmony between the learning process and the test that was tested. During this time the test instrument given the orientation is still low-level thinking, this is what makes student learning outcomes still low, because it is not in line between the learning process provided with the given test. From the results of the question and answer session for students, students felt that the assignment had indeed taken up time and effort, so that when the exams were conducted they felt they could no longer study, because they had to complete the assignments. Actually this must be known by students, that by completing 6 tasks, they have taken the learning process with high level skills, so that it requires extra time and energy. For that, the test requires tests that are oriented towards higher-order thinking skills.

Assessment is one of the main components in the learning process (Wijayanti, 2014). Assessment is not only focused on the cognitive domain, but also focuses on the affective and psychomotor domains (skills). This is in accordance with the assessment carried out in Unimed based on the Chancellor Decree No. 065 / UN33 / Kep / 2016 which is the beginning of the beginning of lectures using an IQF-based curriculum. Aspects of understanding, application and reasoning in the realm of cognitive abilities can be used to show the profile of thinking ability (Rofiah, 2013).

\section{Methodology}

The research method used in this research is research and development methods Research and Development( $R \& D$ ). $R \& D$ research is used to design products or procedures that are systematically tested in the field, evaluated, and developed in a way that meets the criteria of effectiveness, quality or similarity to a standard (Borg and Gall, 2003). The R \& D research used in this study was adapted from Borg and Gall (2003), based on figure 1. 


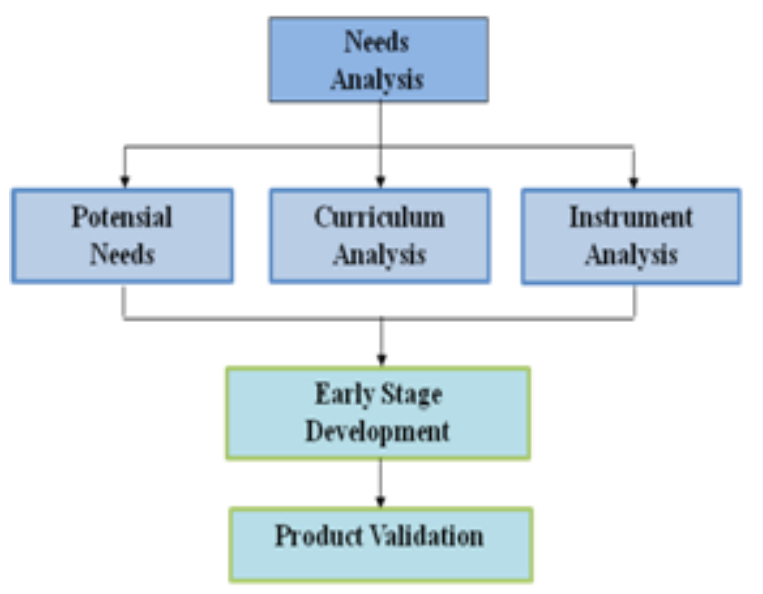

Fig. 1. Research Chart

\section{Result And Discussion}

\subsection{Need Analysis}

At this stage, it is analyzed in three aspects, namely 1) potential of the system; 2) curriculum analysis; and 3) Analysis of Test Instruments

\subsubsection{Potential Needs}

Medan State University, especially the Faculty of Mathematics and Natural Sciences, is a Faculty that has the most potential number of students at the State University of Medan. Facilities and infrastructure that are sufficient enough to allow students to learn and find learning resources. For example the existence of digital Liberary is very helpful for students to find references. Then the existence of internet access that can be used as a medium to find references in cyberspace, such as to search for journals and scientific articles of good quality both nationally and internationally.

\subsection{Curriculum Analysis}

At this stage, the curriculum applied at FMIPA Unimed was analyzed, where Unimed had implemented the Indonesian National Qualifications Framework (KKNI) Curriculum starting in 2016 whose assessment was determined in the Rector's decree. One characteristic of the implementation of the IQF is the implementation of 6 tasks, namely: 1) Routine Tasks; 2) Critical Book Report (CBR); 3) Crtical Journal Review (CJR); 4) Idea Engineering; ) Mini Research (MR); and 6) Project. In detail the explanation of the 6 tasks is:

1. Routine assignments give meaning to train all competencies in converting lectures, with assessment indicators are attitudes, knowledge and skills. 
2. Critical Book Report (CBR) gives meaning to reviewing books based on concepts or theories learned in a course to determine critical positions. Assessment indicators include 1) summary of the problem; 2) consider the context and assumptions; 3) communicating their own perspectives, hypotheses or conjectures; 4) analysis of supporting data and evidence; 5) using other perspectives and conjectures; 6) examine conclusions, implications and consequences; and 7) communicate effectively.

3. Crtical Journal Review (CJR) gives the meaning of critically reviewing (all components of a research) or journal with the main objective of finding the advantages and disadvantages of a research / journal and displaying relevant suggestions to maintain strength and overcome the weaknesses of the research / journal. Indicator. Assessment indicators include: 1) a summary of the background of the research problem; 2) consider the context and assumptions; 3) communicating their own perspectives, hypotheses, or conjectures; 4) analysis of supporting data and evidence; 5) using other perspectives and conjectures; 6) examine conclusions, implications and consequences; and 7) communicate effectively.

4. Rekayation Idea (RI) gives meaning: a) derivation of new ideas or concepts from existing ideas and new ideas in the same or different social context, creation and innovation of existing ideas, b) potential to produce real products, c ) the wild idea (wield idea) that is tamed. Indicators Assessment includes: 1) the ability to produce ideas; 2) describe ideas; 3) Writing engineered ideas; 4) Using current references; 5) Integration Skills.

5. Mini Reserach (MR) gives the meaning of simple research which consists of questions (hypotheses, objectives, main), theories, instruments, data collection, data analysis, and conclusions. The assessment indicators include: 1) Updating and originality; 2) suitability of the purpose formulation; 3) interlocking between elements; 4) appropriateness of the instrument; 5) suitability of data analysis techniques; 6) main findings; and 7) implications.

6. The project gives meaning: a) the application of knowledge transfer for authentic problem solving through the process of investigating ideas, inqury processes, critical and creative thinking, and skillfully nominating the results. b) produce models or products that have ethical, aesthetic, social, cultural and economic values. Assessment indicators include: 1) Inquiry ability in investigating ideas and questions; 2) The ability to apply concepts and principles of science learned in various relevant fields of science; 3) Ability to think creatively in problem solving (fluency, flexibility, elaboration, and novelty of solving strategies); 4) Ability to manage resources to complete tasks; and 5) Reporting ability.

Through these 6 tasks, students are expected to be able to develop their abilities in expressing inspirational and creative ideas. By doing routine tasks, students can achieve the competence of each material taught. The critical Book Report and Critical Journal Review tasks will foster a critical attitude of students, this is based on the characteristics of HOTS itself. So by working on CBR and CJR assignments students have done high-level thinking reasoning (HOTS). The assignment of Idea Engineering, Mini Research and Projects has an impact on students on the habit of giving ideas or ideas that are good for self-development in the students themselves, and for transferring knowledge that is understood so that the learning process is more meaningful (Boorkhart, 2010).

Besides that, the purpose of giving 6 assignments is also expected to be able to implement 10 characters recommended by Medan State University, namely: 1) communication ethics, 2) Honesty, 3) Responsibility, 4) Cooperation, 5) Resilience, 6) Concern, 7 ) Discipline, 8) Perseverance, 9) Independence, 10) Initiative.

Attitude assessment is done by making a range of scales from $1-4$. Where the rating scale is divided into 4 categories, namely: 
Table 1. Assesment Attitude Range

\begin{tabular}{cc}
\hline Attitude Value & Category \\
\hline $3,51-4,00$ & Very good \\
$2,51-3,50$ & Good \\
$1,51-2,50$ & Not good \\
$0,00-1,50$ & Very Poor \\
Attitude Value & Category \\
\hline
\end{tabular}

\subsection{Instrument Analysis}

Before conducting a test analysis given to students, an analysis of the learning device, namely the semester plan learning (RPL).

Table 2. CPL Physics Education Study Program

\begin{tabular}{cc}
\hline A & $\begin{array}{c}\text { Have a professional attitude and openness to collaborate } \\
\text { and have social sensitivity and concern for the } \\
\text { community and the environment for the development of } \\
\text { learning }\end{array}$ \\
\hline $\mathrm{N} \quad \begin{array}{c}\text { Mastering the concept of physics, the scientific mindset } \\
\text { of physics based on natural phenomena needed to carry } \\
\text { out learning in elementary, secondary and advanced } \\
\text { education units }\end{array}$ \\
Able to apply logical thinking, critical, systematic, and \\
innovative in the context of the development or \\
implementation of science and technology that pay \\
attention to and apply the value of humanities in \\
accordance with the field of Physics Education based on \\
rules, procedures and scientific ethics in order to produce \\
solutions, ideas and designs. \\
Able to utilize various alternative solutions to physical \\
problems that have been available independently or in \\
groups for the right decision making in the field of \\
education in classroom learning, physics laboratories and \\
educational institutions that are their responsibility.
\end{tabular}

Based on the learning achievement of the physics education study program shows that the learning achievement has indicated from the characteristics of high-level thinking skills, this can be seen from the general skills of applying logical, systematic, and innovative thinking. Likewise for special skills, namely utilizing alternative problem solving. This is exactly what Susan M. Brookrhat said that high-level thinking has meaning in problem solving.

The following is a learning achievement of basic mechanics and heat courses.

1. Observe the theories, concepts, principles, laws and physics propositions in the study of General Physics I through the study of kinematics in one dimension and two dimensions, particle dynamics, effort and energy, linear momentum, collisions and implus, rotation, equilibrium, static fluid, dynamic fluid, temperature and heat, and ideal gas.

2. Conduct experiments according to his theory and have scientific process skills, critical, and problem solving abilities

3. Applying it in everyday life and as a basis for understanding advanced physics 
Based on the learning achievement of the next course, it will be reduced to the learning achievement of the subject as follows:

1. Assessing kinematics of motion in one and two dimensions, solving problems and applying them in daily life

2. Assessing particle dynamics, solving problems and applying them in daily life

3. Assess business and energy, solve problems and apply them in daily life

4. Assessing linear momentum, collisions and impulses, solving problems and applying them in daily life

5. Assessing rotation and equilibrium, solving problems and applying them in daily life

6. Assessing static and dynamic fluids, solving problems and applying them in daily life

7. Assessing temperature and heat, solving problems and applying them in daily life

8. 8. Assess ideal gas, solve problems and apply them in daily life.

From the learning achievement of the physics education study program and the learning achievement of basic mechanics and heat courses there is a lack of synchronization.

Furthermore, to synchronize the learning achievement of the course is made by paying attention to the characteristics of high-level thinking skills (HOTS) as follows.

1. Making alternative solutions based on natural phenomena and cases needed to develop knowledge in learning.

2. Solving problems through logical thinking, critical, systematic, and innovative in the context of the development or implementation of science and technology

3. Make decisions through alternative physical problem solving that has been available independently or in groups

4. Producing products that can be used in the application of humanities in accordance with the field of Physics Education based on rules, procedures and scientific ethics in order to produce solutions, ideas and designs.

5. Using physics technology in learning, experimentation and research.

For sub-learning achievement courses can be described as follows:

1. Identify the problem based on the facts / cases presented.

2. Interpreting relationships between variables based on facts / cases presented.

3. Formulate problems from facts / cases based on individual perceptions.

4. Presenting ideas from facts / cases as solutions to problem solving given.

5. Applying ideas / ideas through experiments

6. Conduct trials by manipulating variables through the experimental method.

7. Adjust various knowledge used in different contexts.

8. Apply procedures to specific situations.

9. Discriminating facts / cases from hypotheses

10. Distinguish the level of relevance of the hypothesis

11. Justify the material based on the concept

12. Analyze the relationship between solutions and problems

13. Evaluate the stages / procedures of the experiments carried out.

14. Proving the possibility of results

15. Constructing product design as an alternative solution that is utilized in learning.

16. Produce product development planning as an alternative solution that is used in learning. 
17. Using products in the physical feasibility test of products in learning, experiment and research.

After reviewing the RPL of the basic of mechanics and calor, then the analysis of the test instruments was carried out on the final semester examination test based on the Bloom taxonomic percentage of revision, namely $\mathrm{C} 1$ to $\mathrm{C} 6$.

Table 3. Percentage of Cognitif Domain Instrument

\begin{tabular}{ccccccc}
\hline Topic & \multicolumn{7}{c}{ Percentage of cognitive domain } \\
\cline { 2 - 7 } & C1 & C2 & C3 & C4 & C5 & C6 \\
\hline Kinematics & 2 & 4 & 2 & 2 & 0 & 0 \\
Particle Dynamics & 4 & 4 & 4 & 0 & 2 & 0 \\
Work and Energy & 2 & 2 & 4 & 2 & 0 & 0 \\
Momentum \& & 4 & 4 & 2 & 2 & 2 & 0 \\
$\quad$ Impulse & & & & & & \\
$\quad$ Rygid Body & 4 & 4 & 4 & 0 & 0 & 0 \\
Dynamics Rotation & & & & & & \\
Fluid Mechanics & 4 & 2 & 2 & 2 & 0 & 0 \\
Temperature and & 4 & 4 & 4 & 2 & 2 & 0 \\
$\quad$ Calor & & & & & & \\
$\quad$ Kinematics & 2 & 4 & 2 & 2 & 0 & 0 \\
Gas Kinetic Theory & 4 & 4 & 4 & 2 & 0 & 0 \\
Total & 28 & 86 & 26 & 12 & 6 & 0 \\
\hline
\end{tabular}

From the percentage of the final semester exam questions it was clear that the questions being tested were still in the low-level thinking aspect, which was $82 \%$, while for the highlevel thinking it was only $18 \%$. The difference is still far from learning activities that dominate higher-order thinking, especially on 6 tasks.

\subsection{Development Phase of Test Instruments}

The development of test instruments is carried out by making test grids based on learning outcomes. Because the questions developed are questions that require reasoning and creativity in thinking, the number of questions developed is 12 questions for the mid semester exam and 32 questions for the semester final exam.

Table 4. Number of Test Instruments developed

\begin{tabular}{ccc}
\hline Topic & Jumlah MT & Jumlah FT \\
\hline Kinematics & 3 & 3 \\
Particle Dynamics & 3 & 3 \\
Work and Energy & 3 & 3 \\
Momentum \& & 3 & 3 \\
Impulse & & 5 \\
Rygid Body & & \\
Dynamics Rotation & & 5 \\
Fluid Mechanics & 5 \\
Temperature and & \\
Calor & & 5 \\
Gas Kinetic Theory & \\
Total & 12 & 32 \\
\hline
\end{tabular}




\subsection{Validation of Test Instruments}

Test instruments are made based on the grid, which is then validated by 3 experts from the physics education program. There are 3 aspects of validation, namely material aspects, construction aspects and aspects of language. Then the results of the 3 validators determined the mean value using the Aiken's $\mathrm{V}$ formula. With the formula:

$$
\mathrm{V}=\Sigma \mathrm{S} /[\mathrm{n}(\mathrm{C}-1)]
$$

Table 5. Content Validity on Mid Test Instrument

\begin{tabular}{ccc}
\hline No. Item & Value $\mathbf{~}$ & Information \\
\hline 1. & 0,75 & valid \\
2. & 0,75 & valid \\
3. & 0,92 & valid \\
4. & 0,83 & valid \\
5. & 0,75 & Valid \\
6. & 0,83 & Valid \\
7. & 0,67 & Valid \\
8. & 0,58 & Valid \\
9. & 0,42 & Valid \\
11. & 0,92 & Valid \\
12. & 0,83 & Valid \\
\hline
\end{tabular}

In general, the test instruments on mid semester exam questions have valid test validity, although there are some questions that need major and minor improvements.

Table 6. Content Validity on Final Test Instrument

\begin{tabular}{cccccc}
\hline No. Item & Value V & Inf. & No. Item & Value V & Inf. \\
\hline 1. & 0,92 & Valid & 17. & 0,75 & Valid \\
2. & 0,83 & Valid & 18. & 0,67 & Valid \\
3. & 0,67 & Valid & 19. & 0,92 & Valid \\
4. & 0,83 & Valid & 20. & 0,83 & Valid \\
5. & 0,67 & Valid & 21. & 0,67 & Valid \\
6. & 0,92 & Valid & 22. & 0,67 & Valid \\
7. & 0,92 & Valid & 23. & 0,83 & Valid \\
8. & 0,92 & Valid & 24. & 0,92 & Valid \\
9. & 0,83 & Valid & 25. & 0,25 & Not Valid \\
10. & 0,67 & Valid & 26. & 0,67 & Valid \\
11. & 0,75 & Valid & 27. & 0,83 & Valid \\
12. & 0,33 & No Valid & 28. & 0,67 & Valid \\
13. & 0,67 & Valid & 29. & 0,92 & Valid \\
14. & 0,83 & Valid & 30. & 0,67 & Valid \\
15. & 0,50 & Valid & 31. & 0,75 & Valid \\
16. & 0,83 & Valid & 32. & 0,92 & Valid \\
\hline
\end{tabular}


In general, the test instruments developed in mid semester questions are valid, although there are some that must be revised.

Table 7. Content Validity on Final Test Instrument.

\begin{tabular}{cccccc}
\hline No. Item & Value V & Inf. & No. Item & Value V & Inf. \\
\hline 1. & 0,92 & Valid & 17. & 0,75 & Valid \\
2. & 0,83 & Valid & 18. & 0,67 & Valid \\
3. & 0,67 & Valid & 19. & 0,92 & Valid \\
4. & 0,83 & Valid & 20. & 0,83 & Valid \\
5. & 0,67 & Valid & 21. & 0,67 & Valid \\
6. & 0,92 & Valid & 22. & 0,67 & Valid \\
7. & 0,92 & Valid & 23. & 0,83 & Valid \\
8. & 0,92 & Valid & 24. & 0,92 & Valid \\
9. & 0,83 & Valid & 25. & 0,25 & Not Valid \\
10. & 0,67 & Valid & 26. & 0,67 & Valid \\
11. & 0,75 & Valid & 27. & 0,83 & Valid \\
12. & 0,33 & No Valid & 28. & 0,67 & Valid \\
13. & 0,67 & Valid & 29. & 0,92 & Valid \\
14. & 0,83 & Valid & 30. & 0,67 & Valid \\
15. & 0,50 & Valid & 31. & 0,75 & Valid \\
16. & 0,83 & Valid & 32. & 0,92 & Valid \\
\hline
\end{tabular}

The test instruments developed for the semester final exam were 32 questions, and valid questions were 30 questions and 2 questions were invalid. Of the 30 valid questions 7 questions (\%) do not need improvement, 11 questions (\%) need minor improvements, and 12 questions $(\%)$ need major improvements.

\section{Conclusion}

Based on the results of the making of Higher Order Thinking Skill (HOTS) based test instruments in the Basic Mechanics and Heat subjects, it can be concluded as follows:

1. The test results of the validity of the tests by experts indicate that the test instruments developed are valid and can be used for testing into the field.

2. Test instruments developed in good categories in accordance with indicators of higher order thinking skills.

\section{References}

[1] Abosalem, Y., 2016. Assesment Techniques and Studnets' Higher Order Thinking Skilss. Internstional Journal and Secondary Educations (Online).

[2] Asyhari, A., Widha S., Sarwanto. 2014. Pengembangan Perangkat Pembelajaran Fisika SMA Berbasis Inkuiri Terbimbing Terintegrasi Pendidikan Karakter. Jurnal Inkuiri. 5(1); 62-75

[3] Borg, Walter; Gall, Meredith, etc. (2003). Educational Research An Introduction 7th Edition. Boston: Pearson Education Inc.

[4] Boorkhart, M.S., 2010. Higher Order Thinking Skills in Your Classroom. ASDC Publication USA.

[5] Dimyati, Mudjiono, 2006. Belajar dan Pembelajaran. Jakarta : PT. Rineka Cipta 
[6] Goudas, M. 2006. The Effectiveness of Teaching A Life Skills Program in A Physical Education Context. European Journal of Psychology of Education. 21: 429-438

[7] Haladyna, T.M., 2004. Developing and Validating Multiple-Choice Test Items. New Jersey : Lawrence Erlbaum Associates. 3thEdition

[8] Kusuma, D., M., Rosidin, U., Abdurrahmah, Suyatna, A., 2017. The Development of Higher Order Thinking Skills (HOTS) Instrument Assesment in Physics Study. IORS-Journal of Reserach \& Method in Education (IOSR-JRME).

[9] Mohamed, R., Lebar, Othman, 2017. Authentic Assessment in Assesing Higher Order Thinking Skills. International Journal of Academic Research in Business and Social Science. Vol. 7. No. 2. Page : $466-476$.

[10] Retnawati, H., 2016. Proving Content Validity of Self Regulated Learning Scale (The Comparison of Aiken Index and Expanded Gregory Index). Research and Evaluation Education (REID). Vol. 2. Page : 155 - 164

[11] Retnawati H, 2016. Analisis Kuantitatif Instrumen Penelitian, Parama Publishing : Yogyakarta [12] Rofiah, E., Aminah, S. N., Ekawati, Y.E., 2013. Penyusunan Tes Kemampuan Berpikir Tingkat Tinggi Fisika pada Siswa SMP. Jurnal Pendidikan Fisika. Vol. 1 No. 2. Hal. 17 - 22.

Schunk, D.H., Zimmerman, B. J., 1998. Self Regulated Learning: From Teaching to Self-Reflective Practise, New York: The Guilford Press

[13] Toharudin, U, Hendrawati, S, dan Rustaman, A. 2011. Membangun Literasi Sains Peserta Didik. Bandung: Humaniora.

[14] Wardany, K., Sajidan, Ramli, M., 2015. Penysunan Intrumen Tes Higher Order Thinking Skill pada Materi Ekosistem SMA Kelas X. Seminar Nasional XII Pendidikan Biologi FKIP UNS.

[15] Wijayanti, A., 2014. Pengmebangan Autentic Assessment Berbasis Proyek Dengan Pendekatan Saintifik Untuk Meningkatkan Keterampilan Berpikil Ilmiah Mahasiswa. Jurnal Pendidikan IPA Indonesia. Vol. 3. NO. 2. Hal. $102-108$.

[16] Winarti, Cari, Sunarno, W., Istiyono, E., 2015. Analysis of Higer Order Tihinking Skills Content of Physics Examination in Madrasyah. Internationals of Mathematics, Science, and Education (ICMSE). Semarang State University. 